\title{
Matrix metalloproteinase-2 and -9 secretion by the human JAR choriocarcinoma cell line is stimulated by TNF- $\alpha$
}

\author{
Benoît Chénais ${ }^{1,2}$ \\ ${ }^{1}$ School of Pharmacy, University of Reims-Champagne Ardenne, Reims, France \\ ${ }^{2}$ Department of Biology, Université du Maine, Le Mans, France \\ Email: bchenais@univ-lemans.fr
}

Received 6 October 2011; revised 12 November 2011; accepted 19 December 2011

\begin{abstract}
The JAR choriocarcinoma cell line share many of the characteristics of early placental trophoblast cells including the invasion properties. Matrix metallo-proteinases (MMPs), the main actors of matrix proteolysis, are involved in normal invasion as well as in the invasive character of tumor cells and the metastase formation. Tumor necrosis factor- $\alpha$ (TNF- $\alpha$ ) is present in the placental environment and TNF- $\alpha$ levels are elevated in some placental pathologies. In the present work, we addressed whether TNF- $\alpha$ is a modulator of JAR cell MMP secretion. Following TNF- $\alpha$ stimulation, zymographic analysis showed the increased secretion of the active form of MMP-2 and to a lesser extent proMMP-2 and MMP-9. In addition, MMP-2 gene expression only increased slightly whereas MMP-9 and TIMP-1 transcripts were undetectable. This suggests that TNF- $\alpha$ may modulate the secretion of MMPs independently of MMP gene expression control.
\end{abstract}

Keywords: JAR Cell; Matrix Metalloproteinase; Tumor Necrosis Factor- $\alpha$

\section{INTRODUCTION}

The human placenta is a unique transient organ and its capacity to proliferate and to invade maternal tissues is qualities that are usually found in malignant tumors. However, growth and invasion at the fetal-maternal interface is under tight control, and malignant placental tumors are rare [1]. Normal trophoblast cells as well as malignant choriocarcinoma cells including the JAR, BeWo and JEG-3 cell lines, derived from trophoblastic tumors of the human placenta, have served as models, even if imperfect, to study placental cells [2]. The JAR cell line shares many early placental trophoblast cell characteristics, such as synthesis of human chorionic gonadotropin and steroids [3], and the ability to differentiate into syn- cytiotrophoblast-like cells in vitro [4].

Proper invasion is critical for placental and fetal development and its dysregulation results in several pregnancy abnormalities [5-8]. The process of physiological invasion is tightly regulated in space and time by invasion-promoting (e.g. epidermal growth factor, endothelin-1, insulin-like growth factor-I and-II, etc.) and invasion-inhibiting factors (e.g. tissue inhibitor of metalloproteinases-1 (TIMP-1), transforming growth factor $\beta \ldots$ ) that bind to receptors expressed on the extravillous trophoblasts [9]. These invasion regulating factors either originate from the maternal decidua, the villous stroma or are secreted by various trophoblast populations.

Tumor necrosis factor- $\alpha$ (TNF- $\alpha$ ) is a cytokine believed to have important functions during pregnancy $[10$, 11]. Circulating levels of TNF- $\alpha$ are elevated in preeclampsia and in pathological placental tissue derived from intrauterine growth-restricted pregnancies $[12,13]$. TNF- $\alpha$ is produced and secreted by trophoblasts and decidual macrophages and it may either promote $[14,15]$ or limit $[16,17]$ normal trophoblast invasion. Both placental cytotrophoblasts and choriocarcinoma cell lines, includeing JAR cells, express members of the TNF receptor superfamily [18].

Matrix metalloproteinases (MMPs), the main actors of matrix proteolysis and the secretion of MMPs, is involved in the normal invasion process as well as in the invasive character of tumor cells and metastase formation [19]. MMPs are a family of zinc- and calcium-dependant proteolytic enzymes, which should be activated by prodomain proteolytic cleavage, or the alteration of its structure $[19,20]$. Both pro-MMPs and active MMPs may be inhibited by metalloproteinase tissue inhibitors (TIMPs) that are secreted by MMPs [20]. Thus, the invasive character of cells is determined by the protease/inhibitor ratio [19,20]. Analyses of MMP and TIMP secretion and activity in trophoblats and trophoblast-derived cells point out the role of gelatinase-A (MMP-9) and gelatinase-B (MMP-2) in the high invasive capacity of first trimester trophoblasts and support the role of metal-loproteinases 2 
and 9 during pregnancy [21-23]. However MMP expression patterns may be different between normal trophoblasts and choriocarcinoma cells $[24,25]$ and may vary between early and late trophoblasts [26,27].

In the present work we have investigated the secretion of MMPs in the JAR choriocarcinoma cell line upon TNF- $\alpha$ stimulation. Zymographic analysis shows the increased secretion of the active form of MMP-2, and to a lesser extent pro MMP-2 and MMP-9, following TNF- $\alpha$ stimulation. In addition MMP-2 gene expression only increased slightly whereas MMP-9 and TIMP-1 transcripts were undetectable.

\section{MATERIAL AND METHODS}

\subsection{Cell Culture Conditions}

The human JAR choriocarcinoma cell line [28] was cultivated in RPMI-1640 plus glutamax ${ }^{\circledR}$ medium (Life Technologies) supplemented with $5 \%$ fetal calf serum (FCS) in a $5 \% \mathrm{CO}_{2}$ atmosphere at $37^{\circ} \mathrm{C}$. For further experiments cell cultures were sown with 300,000 cells per well in six well plates (Nunc), and reached confluence in $48 \mathrm{~h}$.

Since the presence of FCS in a culture medium may affect MMP zymographic analysis, the viability of JAR cells in an FCS depleted medium was checked. Cells were first cultivated in the presence of either $1 \%, 2 \%$ or $5 \%$ of FCS for $48 \mathrm{~h}$; then in an FCS-free medium for additional $24 \mathrm{~h}, 48 \mathrm{~h}$ or $72 \mathrm{~h}$. Cell viability decreased strongly with the lower concentration of FCS whereas the presence of $5 \%$ of FCS allowed a good proliferation of JAR cells and an acceptable survival rate during serum starvation. Zymographic analysis of gelatinase activity did not reveal strong differences between each of these culture conditions. Then following experiments were performed using a $48 \mathrm{~h}$ proliferation step in the presence of 5\% FCS followed by a serum starvation step of $24-48 \mathrm{~h}$. These culture conditions produced a good proliferation of cells together with a serum free environment as required for zymographic analysis.

\subsection{Zymographic Analysis of Gelatinase Activity}

Gelatinolytic activity determination is a very sensitive way to measure MMP-2 and MMP-9 production [29]. Using cell culture supernatants we access to the secreted MMPs, including the pro and active forms of gelatinases as described previously [30,31]. Briefly, an appropriate volume of cell culture supernatant corresponding to an equal amount of cells $\left(1.5 \times 10^{3}\right.$ cells $)$ was applied to $10 \%$ SDS-polyacrylamide gels containing $1 \mathrm{mg} / \mathrm{ml}$ gelatin. After migration, SDS was removed by two incubations in 2\% Triton X-100 for $30 \mathrm{~min}$. Then the gelatinases were activated by overnight incubation at $37^{\circ} \mathrm{C}$ in
$50 \mathrm{mM}$ Tris- $\mathrm{HCl} \mathrm{pH} 7.4,0.2 \mathrm{M} \mathrm{NaCl}$ and $5 \mathrm{mM} \mathrm{CaCl}_{2}$. Proteolytic activities were evidenced as clear bands against the blue background of the Coomassie bluestained gelatin. The human fibrosarcoma HT-1080 cell line, which constitutively secrete proMMP-9 $(92 \mathrm{kDa})$ and proMMP-2 (72 kDa) [32], was used as an internal control for MMP expression [30,31].

\subsection{Semi-Quantitative RT-PCR Gene Expression Analysis}

After removing culture media, cells were lysed in Trizol ${ }^{\circledR}$ reagent (Invitrogen) and total RNA were extracted according to standard procedures [33]. One $\mu \mathrm{g}$ of RNA was reverse-transcribed using oligodT primers and AMV reverse transcriptase (Promega) following manufacturer's conditions. The resulting cDNAs were diluted $1 / 5$ before PCR amplification. PCR conditions and primers for MMP-2, MMP-9, TIMP-1, and GAPDH were as previously described $[30,31]$. The primers used for NRF-3 amplification were 5'-GGCAGGAAAAGACCACTGA3' and 5'-GACTTATAGCCTGGCTGA-3' with the following PCR conditions: $94^{\circ} \mathrm{C}, 30 \mathrm{sec} ; 60^{\circ} \mathrm{C}, 30 \mathrm{sec} ; 72^{\circ} \mathrm{C}$ $60 \mathrm{sec}$ for 33 cycles. PCR products were then analysed using $1 \%$ agarose gel electrophoresis and a densitometric quantification was performed using the Amersham Biosciences Typhoon 9210 system.

\section{RESULTS}

\subsection{Increased Secretion of MMPs by JAR Cells Stimulated with TNF- $\alpha$}

Zymographic analysis of cell culture media showed that JAR cells constitutively secreted both proMMP-2 and active MMP-2 (Figure 1(a)). According to previous reports $[27,34,35]$ pro-MMP-9 and MMP-9 secretion is barely detectable in a JAR cell culture medium (Figure 1(a)). In order to determine the effect of TNF- $\alpha$, cells were stimulated with $20 \mathrm{ng} / \mathrm{mL}$ of TNF- $\alpha$ during the serum starvation step. The results of zymographic analysis show a significant increase of MMP-2 secretion (Figure 1(a)). The secretion of active MMP-2 was 2-fold higher in the $24 \mathrm{~h}$ culture medium of TNF- $\alpha$ treated JAR cells, and reached a 4 -fold increase at $48 \mathrm{~h}$ (Figure 1(b)). However, the increase of proMMP-2 secretion was moderate ( 1.2 and 1.5 fold at $24 \mathrm{~h}$ and $48 \mathrm{~h}$ times points, respectively) but statistically significant ( $p<0.05$, Figure 1(c)). According to previous reports, the level of MMP-9 secreted by untreated JAR cells is very low and often barely detectable whereas proMMP-9 could not be detected (Figure 1(a)). However active MMP-9 secretion seems to have increased slightly (1.2-fold) after cell stimulation by TNF- $\alpha$ in a $48 \mathrm{~h}$ cell culture medium (Figure 1(d)). 


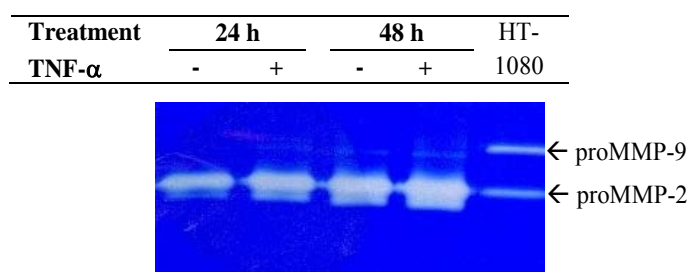

(a)

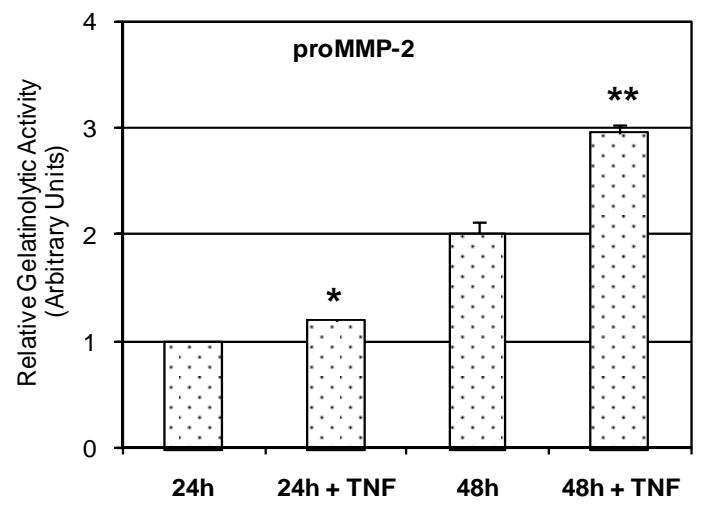

(c)

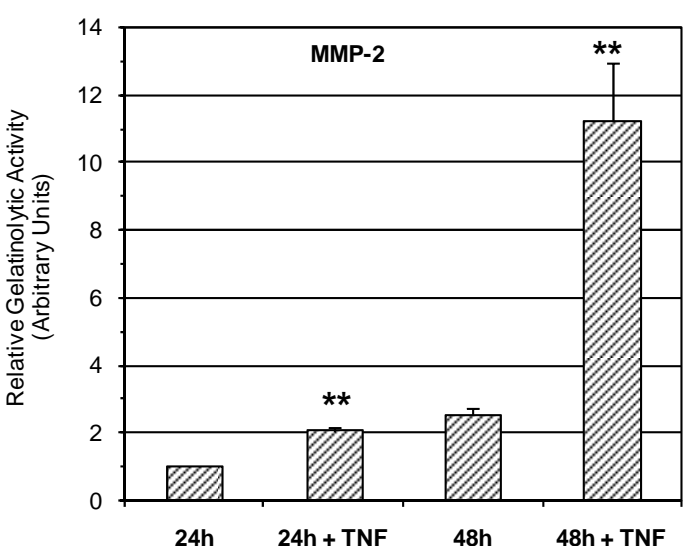

(b)

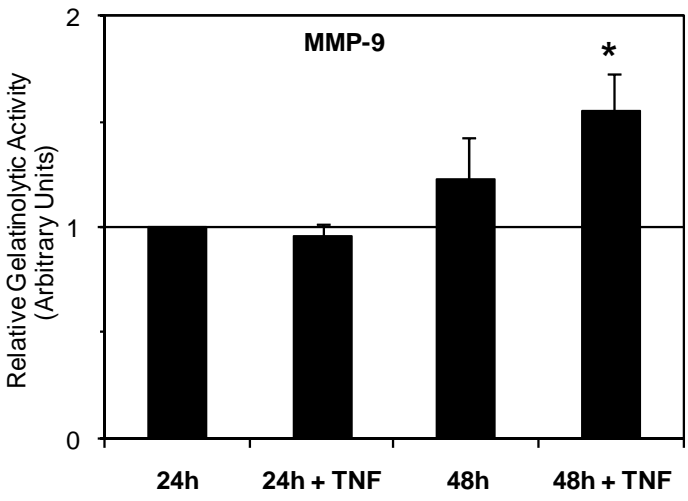

(d)

Figure 1. Secretion of MMPs by JAR cells is stimulated by TNF- $\alpha$. (a) Zymmographic analysis of the gelatinolytic activity of JAR cell culture medium in the presence or absence of TNF- $\alpha(20 \mathrm{ng} / \mathrm{mL})$ for $24 \mathrm{~h}$ and $48 \mathrm{~h}$. The HT-1080 cell culture supernatant was used as an indicator of pro-MMP-2 and pro-MMP-9 position. Zymmograms from one representative experiments; (b) Densitometric quantification of zymmograms using the Typhoon 9210 apparatus (Amersham Bioscience). Results are the means \pm standard deviation of three independent experiments, asterisks indicate a value significantly different from the control without TNF- $\alpha$ at the same time point according to paired Student $\mathrm{t}$ test $\left({ }^{*} \mathrm{p}<0.05 ; * * \mathrm{p}<0.01\right)$.

\subsection{MMP-2 Gene Expression Is Stimulated by TNF- $\alpha$ in JAR Cells}

The increased MMP secretion in the presence of TNF- $\alpha$ may, at least partly, be due to transcriptional activation of MMP genes as previously described for MMP-9 or MMP-15 in normal trophoblasts $[14,15,36]$. As shown in Figure 2, MMP-2 gene expression increased slightly in JAR cells treated with TNF- $\alpha$ for 24 h (1.4-fold). However, MMP-9 and TIMP-1 gene expression was undetectable at both time points. As a control of the TNF- $\alpha$ effect on gene expression in the present experimental conditions, the NRF-3 transcription factor expression was increased in JAR cells stimulated by TNF- $\alpha$ for $24 \mathrm{~h}$ (Figure 2) according to our previous report [33]. It should be noted that the TNF- $\alpha$ effect on MMP-2 and NRF3 gene expression was only observed at the $24 \mathrm{~h}$ time point and that gene expression returned to control level at $48 \mathrm{~h}$.

\section{DISCUSSION}

Cytokines can cause either harmful or beneficial outcomes in pregnancy, for example, an overproduction of interferon $\gamma$ and TNF- $\alpha$ may be associated with recurrent spontaneous abortions in humans and fetal loss in mice [37-39]. These cytokines are also found in normal decidual and placental tissues, and accumulating evidence suggests physiological roles for these factors in regulating trophoblast invasion, spiral artery modification, and placental morphogenesis [14,40,41]. The JAR choriocarcinoma cell line express TNF receptors [18] and its invasive characteristics may then be affected by TNF- $\alpha$ stimulation. Accounting for the central role of MMPs in the invasion process we investigated whether TNF- $\alpha$ may be a modulator of MMP secretion and/or gene expression in JAR cells.

According to previous studies [27,34,35], we show here that the JAR choriocarcinoma cell line constitutively 


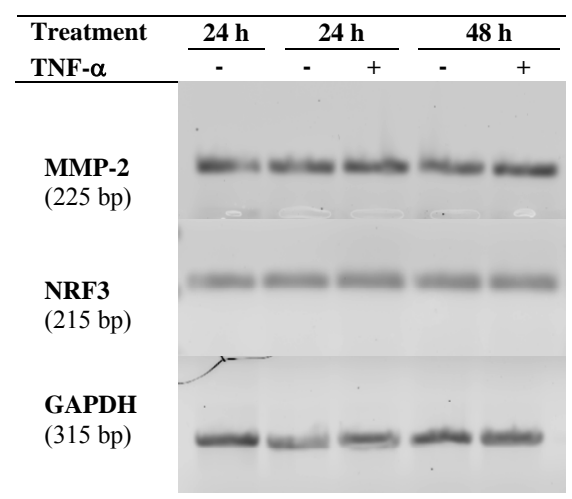

(a)

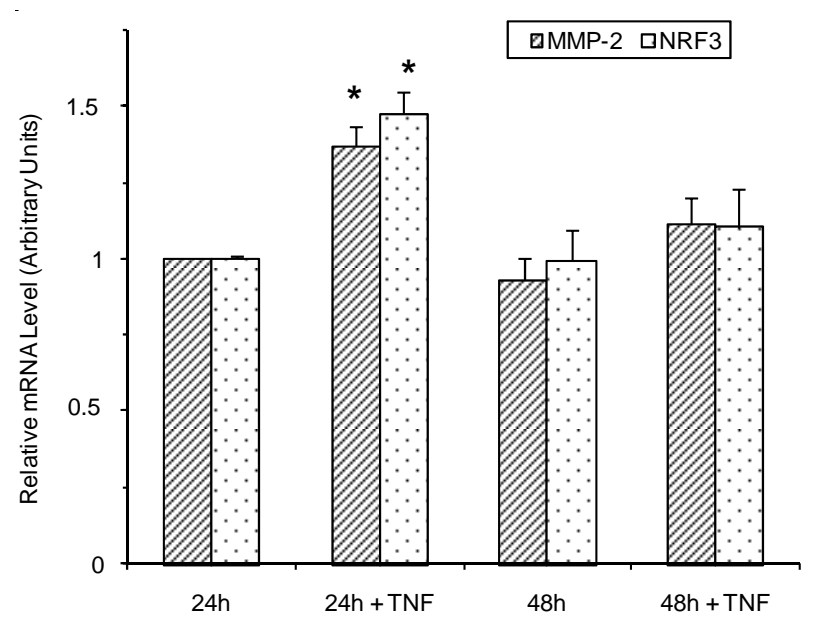

(b)

Figure 2. Semi-quantitative RT-PCR analysis of MMP-2 and NRF3 gene expression. Total RNA were extracted from JAR cells stimulated or not with TNF- $\alpha$ for $24 \mathrm{~h}$ and $48 \mathrm{~h}$, and thereafter used for semi-quantitative RT-PCR as described in the Materials and Methods section. (a) Amplification products separation on agarose gel; (b) Quantification was performed using Typhoon 9210 apparatus (Amersham Bioscience) and the relative mRNA level was calculated with respect to the GAPDH mRNA level. Results are the means \pm standard deviation of three independent experiments, asterisk $(*)$ indicate a value significantly different from the control without TNF- $\alpha$ at the same time point according to paired Student $t$ test $(p<$ $0.01)$.

secretes pro and active forms of MMP-2. In addition MMP-9 and TIMP-1 gene expression was undetectable in JAR cells in agreement with the results of Shröpfer et al. [27]. Cell treatment by TNF- $\alpha$ is known to induce gene expression in several cellular models involving various intracellular signaling pathways includeing the NF$\kappa \mathrm{B}$ and mitogen activated kinase pathways [42-44]. In relation to our subject, recent reports using normal trophoblast and derived cell lines have described increased MMP-9 and MMP-15 expression following TNF- $\alpha$ stimulation $[14,15,36]$. We have also reported the increased expression of the transcription factor NRF-3 in
JAR cells [33]. We show here that the secretion of pro MMP-2, active MMP-2, and MMP-9 is stimulated by TNF- $\alpha$. However, MMP-2 gene expression only increased slightly and MMP-9 expression remained undetectable after TNF- $\alpha$ treatment. These results suggest that the increased secretion of MMPs may be involved in the upregulation of the secretion process by TNF- $\alpha$ rather than MMP gene activation. Despite MMP-15 (MT2-MMP) expression seeming absent from JAR cells [27], its upregulation by TNF- $\alpha$ in the ACH-P nonmalignant trophoblast cell line has been reported and may be involved in the activation of proMMP2 [36]. Such a mechanism may be present in JAR cells but is still un- known.

The pattern expression of MMPs and TIMPs in first trimester trophoblast and derived cell lines, including choriocarcinoma cells, is quite different [24,25,27]. Interestingly, in early trophoblasts (6 to 8 weeks), as well as in JAR cells, MMP-2 appeared to be the main gelatinase and the key enzyme in trophoblast invasion whereas in late trophoblasts (9 to 12 weeks) both MMP-2 and MMP-9 participated in trophoblast invasion [26]. While we have observed the stimulatory effect of TNF- $\alpha$ on MMP-2 secretion and expression, other authors have recently demonstrated the inhibitory effect of progesterone on MMP-2 expression in JAR cells [45]. One must also note the correlation between increased levels of circulating TNF- $\alpha[12,13]$ and elevated MMP-2 levels observed in the plasma of women who subsequently develop preeclampsia [21]. Our observation in JAR cells may explain such a correlation.

Altogether these results show that MMP-2 is the main actor of JAR cell invasiveness and that MMP-2 expression and secretion may be modulated by inhibitory factors, such as progesterone and stimulatory factors such as TNF- $\alpha$. This may renew interest in the JAR cell line as a model of early first trimester trophoblasts.

\section{ACKNOWLEDGEMENTS}

This work was supported by a grant from the French National League against Cancer, Committee of the Marne. The author is grateful to a PhD student (Doriane Richard) and graduates (Pamela Della Gaspera and Benoît Langlois) who participated in this work, and to Marylin Twell for revising the English text.

\section{REFERENCES}

[1] Bamberger, A.M., et al. (2004) Expression pattern of the activating protein-1 family of transcription factors in the human placenta. Molecular Human Reproduction, 10, 223-228. doi:10.1093/molehr/gah011

[2] Hohn, H.P., Linke, M., Ugele, B. and Denker, H.W. (1998) Differentiation markers and invasiveness: Discordant regulation in normal trophoblast and choriocarcinoma cells. Experimental Cell Research, 244, 249-258. 
doi:10.1006/excr.1998.4184

[3] White, T.E., et al. (1988) Human choriocarcinoma (JAR) cells grown as multicellular spheroids. Placenta, 9, 583598. doi:10.1016/0143-4004(88)90002-1

[4] Grümmer, R., Hohn, H.P., Mareel M.M. and Denker, H.W. (1994) Adhesion and invasion of three human choriocarcinoma cell lines into human endometrium in a threedimensional organ culture system. Placenta, 15, 411-429. doi:10.1016/0143-4004(94)90008-6

[5] Chaddha, V., Viero, S., Huppertz, B. and Kingdom, J. (2004) Developmental biology of the placenta and the origins of placental insufficiency. Seminars in Fetal and Neonatal Medicine, 9, 357-369. doi:10.1016/j.siny.2004.03.006

[6] Kaufmann, P., Black, S. and Huppertz, B. (2003) Endovascular trophoblast invasion: Implications for the pathogenesis of intrauterine growth retardation and preeclampsia. Biology of Reproduction, 69, 1-7. doi:10.1095/biolreprod.102.014977

[7] Goldman-Wohl, D. and Yagel, S. (2002) Regulation of trophoblast invasion: From normal implantation to preeclampsia. Molecular and Cellular Endocrinology, 187, 233-238. doi:10.1016/S0303-7207(01)00687-6

[8] Fisher, S.J. (2004) The placental problem: Linking abnormal cytotrophoblast differentiation to the maternal symptoms of preeclampsia. Reproductive Biology and Endocrinology, 2, 53. doi:10.1186/1477-7827-2-53

[9] Chakraborty, C., Gleeson, L.M., McKinnon, T. and Lala, P.K. (2002) Regulation of human trophoblast migration and invasiveness. Canadian Journal of Physiology and Pharmacology, 80, 116-124.

doi: $10.1139 / \mathrm{y} 02-016$

[10] Argiles, J.M., Carbo, N. and Lopez-Soriano, F.J. (1997) TNF and pregnancy: The paradigm of a complex interacttion. Cytokine and Growth Factor Reviews, 8, 181-188. doi:10.1016/S1359-6101(97)00012-9

[11] Schafer-Somi, S. (2003) Cytokines during early pregnancy of mammals: A review. Animal Reproduction Science, 75, 73-94. doi:10.1016/S0378-4320(02)00222-1

[12] Conrad, K.P. and Benyo, D.F. (1997) Placental cytokines and the pathogenesis of preeclampsia. American Journal of Reproductive Immunology, 37, 240-249. doi:10.1111/j.1600-0897.1997.tb00222.x

[13] Holcberg, G., et al. (2001) Increased production of tumor necrosis factor- $\alpha$ TNF- $\alpha$ by IUGR human placentae. European Journal of Obstetrics \& Gynecology and Reproductive Biology, 94, 69-72. doi:10.1016/S0301-2115(00)00321-3

[14] Cohen, M., Meisser, A., Haenggeli, L. and Bischof P. (2006) Involvement of MAPK pathway in TNF-alpha-induced MMP-9 expression in human trophoblastic cells. Molecular Human Reproduction, 12, 225-232. doi:10.1093/molehr/gal023

[15] Lockwood C.J., et al. (2008) Matrix Metalloproteinase 9 (MMP9) expression in preeclamptic decidua and MMP9 induction by tumor necrosis factor alpha and interleukin 1 beta in human first trimester decidual Cells. Biology of Reproduction, 78, 1064-1072. doi:10.1095/biolreprod.107.063743

[16] Renaud, S.J., et al. (2005) Activated macrophages inhibit human cytotrophoblast invasiveness in vitro. Biology of Reproduction, 73, 237-243. doi:10.1095/biolreprod.104.038000

[17] Otun H.A., et al. (2011) Effect of tumour necrosis factor- $\alpha$ in combination with interferon- $\gamma$ on first trimester extravillous trophoblast invasion. Journal of Reproductive Immunology, 2011, 88, 1-11. doi:10.1016/j.jri.2010.10.003

[18] Phillips, T.A., Ni, J. and Hunt, J.S. (2001) Death-inducing tumour necrosis factor (TNF) superfamily ligands and receptors are transcribed in human placentae, cytotrophoblasts, placental macrophages and placental cell lines. Placenta, 22, 663-672. doi:10.1053/plac.2001.0703

[19] Westermarck, J. and Kahari, V.M. (1999) Regulation of matrix metalloproteinase expression in tumor invasion. FASEB Journal, 13, 781-792.

[20] Brew, K., Dinakarpandian, D. and Nagase, H. (2000) The tissue inhibitors of metalloproteinases (TIMPs): An ancient family with structural and functional diversity. Biochimica et Biophysica Acta, 1477, 267-283. doi:10.1016/S0167-4838(99)00279-4

[21] Myers, J.E., et al., (2005) MMP-2 levels are elevated in the plasma of women who subsequently develop preeclampsia. Hypertension in Pregnancy, 24, 103-115. doi:10.1081/PRG-200059836

[22] Shokry, M., Omran, O.M., Hassan, H.I., Elsedfy, G.O. and Hussein, M.R. (2009) Expression of matrix metalloproteinases 2 and 9 in human trophoblasts of normal and preeclamptic placentas: Preliminary findings. Experimental and Molecular Pathology, 87, 219-225. doi:10.1016/j.yexmp.2009.08.001

[23] Dimo, B., et al. (2011) Comparative study of the immunohistochemical expression of tissue inhibitors of metalloproteinases 1 and 2 between clearly invasive carcinomas and "in situ" trophoblast invasion. Medical Oncology, in press.

[24] Morgan, M., Kniss, D. and McDonnell, S. (1998) Expression of metalloproteinases and their inhibitors in human trophoblast continuous cell lines. Experimental Cell Research, 242, 18-26. doi:10.1006/excr.1997.3929

[25] Singh M., et al. (2011) Matrix metalloproteinases and their inhibitors and inducer in gestational trophoblastic diseases and normal placenta. Gynecologic Oncology, 122, 178-182. doi:10.1016/j.ygyno.2011.03.025

[26] Staun-Ram, E., Goldman, S., Gabarin, D. and Shalev, E. (2004) Expression and importance of matrix metalloproteinase 2 and 9 (MMP-2 and -9) in human trophoblast invasion. Reproductive Biology and Endocrinology, 2, 59. doi:10.1186/1477-7827-2-59

[27] Schröpfer, A., et al. (2010) Expression pattern of matrix metalloproteinases in human gynecological cancer cell lines. BMC Cancer, 10, 553. doi:10.1186/1471-2407-10-553

[28] Pattillo, R.A., Ruckert, A.C., Hussa, R.O., Bernstein, R. and Delfs, E. (1971) The JAR cell line, continuous human multihormone production and controls. In Vitro, 6, 398. 
[29] Heussen, C. and Dowdle, E.B. (1980) Electrophoretic analysis of plasminogen activators in polyacrylamide gels containing sodium dodecyl sulfate and copolymerized substrates. Analytical Biochemistry, 102, 196-202.

[30] Richard, D., Hollender, P. and Chénais B. (2002) Butyric acid increases invasiveness of HL-60 leukemia cells: Role of reactive oxygen species. FEBS Letters, 518, 159-163. doi:10.1016/S0014-5793(02)02690-X

[31] Richard, D., Hollender, P. and Chénais, B. (2002) Involvement of reactive oxygen species in aclarubicin-induced differentiation and invasiveness of HL-60 leukemia cells. International Journal of Oncology, 21, 393-399.

[32] Moll, U.M., Youngleib, G.L., Rosinski, K.B. and Quigley, J.P. (1990) Tumor promoter-stimulated Mr 92,000 gelatinase secreted by normal and malignant human cells: Isolation and characterization of the enzyme from HT1080 tumor cells. Cancer Research, 50, 6162-6170.

[33] Chénais, B., et al. (2005) Functional and placental expression analysis of the human NRF3 transcription factor. Molecular Endocrinology, 19, 125-137.

[34] Staff, A.C., Ranheim, T., Henriksen, T. and Halvorsen, B. (2000) 8-Iso-prostaglandin f(2alpha) reduces trophoblast invasion and matrix metalloproteinase activity. Hypertension, 35, 1307-1313.

[35] Mandl, M., Haas, J., Bischof, P., Nöhammer, G. and Desoye, G. (2002) Serum-dependent effects of IGF-I and insulin on proliferation and invasion of human first trimester trophoblast cell models. Histochemical Cell Biology, 117, 391-399. doi:10.1007/s00418-002-0403-5

[36] Hiden U., et al. (2007) The first trimester human trophoblast cell line ACH-3P: A novel tool to study autocrine/paracrine regulatory loops of human trophoblast subpopulations-TNF- $\alpha$ stimulates MMP15 expression. BMC Developmental Biology, 7, 137. doi:10.1186/1471-213X-7-137

[37] Jenkins C., et al. (2000) Evidence of a T(H) 1 type re- sponse associated with recurrent miscarriage. Fertility and Sterility, 73, 1206-1208. doi:10.1016/S0015-0282(00)00517-3

[38] Mjihdi, A., Truyens, C., Detournay, O. and Carlier Y. (2004) Systemic and placental productions of tumor necrosis factor contribute to induce fetal mortality in mice acutely infected with Trypanosoma cruzi. Experimental Parasitology, 107, 58-64. doi:10.1016/j.exppara.2004.03.016

[39] Kim S., et al. (2005) Interferon-gamma promotes abortion due to Brucella infection in pregnant mice. BMC Microbiology, 5, 22. doi:10.1186/1471-2180-5-22

[40] Scaife, P.J., Bulmer, J.N., Robson, S.C., Innes, B.A. and Searle, R.F. (2006) Effector activity of decidual CD8+ T lymphocytes in early human pregnancy. Biology of Reproduction, 75, 562-567. doi:10.1095/biolreprod.106.052654

[41] Hanna, J. and Mandelboim O. (2007) When killers become helpers. Trends in Immunology, 28, 201-206. doi:10.1016/j.it.2007.03.005

[42] Baud, V. and Karin, M. (2001) Signal transduction by tumor necrosis factor and its relatives. Trends in Cell Biology, 11, 372-377. doi:10.1016/S0962-8924(01)02064-5

[43] Wajant, H., Pfizenmaier, K. and Scheurich, P. (2003) Tumor necrosis factor signalling. Cell Death and Differentiation, 10, 45-65. doi:10.1038/sj.cdd.4401189

[44] Aggarwal, B.B., Shishodia, S., Sandur, S.K., Pandey M.K. and Sethi, G. (2006) Inflammation and cancer: How hot is the link? Biochemical Pharmacology, 72, 1605-1621. doi:10.1016/j.bcp.2006.06.029

[45] Goldman, S., Lovett, D.H. and Shalev, E. (2009) Mechanisms of matrix metalloproteinase-2 (MMP-2) transcriptional repression by progesterone in JAR choriocarcinoma cells. Reproductive Biology and Endocrinology, 7, 41. doi:10.1186/1477-7827-7-41 